\title{
FORMATION OF CREATIVELY IMPROVISED PERSONALITY OF THE SENIOR PRESCHOOL AGE CHILD THROUGH MUSICAL ACTIVITY
}

\section{Lisovska T. A.}

\section{INTRODUCTION}

Art is one of the levers that determines the direction of cultural development of mankind. Given this, the National Strategy for the Development of Education in Ukraine for 2012-2021 (2013) emphasizes the need to increase the influence of musical art on the education and development of a creative personality.

From the point of view of contemporary achievements of art studies, psychological and pedagogical sciences, the musical and aesthetic education and teaching of children and youth requires solving of many artistic and pedagogical problems. The urgent one is the creation of new theoretical developments, effective methods of musical education and upbringing, in particular methods aimed at musical improvisation activity. The history of pedagogical experience shows that musical education has a special place in the spiritual, aesthetic and general cultural development of the child.

However, in the theory and method of musical education of children in a preschool institution, improvisation was not the subject of a special study. In the modern methodology of preschool age children musical education, there are no recommendations for the study taking into account the levels of musical development and the upbringing of preschoolers. Improvisation of the child today is not sufficiently taken into account in the programs of musical education, in the practice of educators and music teachers, which negatively affects the effectiveness of this process.

Thus, there are contradictions between the need for the formation of the creative and improvised personality of senior preschool children in the musical activity and the content of the work of the preschool establishments teachers; the goals of education, due to the variability and flexibility of its content, the lack of means for their reproduction in the content of musical education of preschool age children; the need to 
improve the content, forms and methods of musical education in preschool establishments and the lack of research on the formation of the creatively improvised personality of a senior preschool age child through musical activity.

The urgency of the problem, its insufficient theoretical and practical development led to the choice of the topic of the research, which purpose is theoretical substantiation and testing of pedagogical conditions for the implementation of musical improvisation activities in the formation of the creative personality of a senior preschool age child.

The productivity of experimental methodology, development of fragments of notes (lessons records), creative games and diagnostic tasks are presented by the author. The work carried out has influenced the maintenance of interest in musical improvisation as a whole.

\section{The essence and characteristics of musical and improvisational activities}

Solving the problem of child adaptation of in the society much depends on the direction of the pedagogical process to the creative development of a person capable of responding quickly to possible changes in the musical educational environment. This problem is one of the most urgent in modern pedagogy, for its solution, it is important to determine the ways of purposeful creative development of children of the senior preschool age in the process of musical improvisation activity. It is musical activity that has the most effective influence on the development of creative personality features, since it is a creative process that requires the child to give birth to their own personal-meaningful thoughts and creative expression. After all, music, painting, theater create such a complex of means of artistic expression, which gives freedom of imagination, improvisation, activates the manifestations of intuition and search initiative.

Improvisation manifests itself in the activity, and musical improvisation is in musical activity. Therefore, the logic of the study dictates the need to turn to modern ideas about the specifics of musical activity, improvisation as a specific type of musical improvisation activity.

In modern terminology literature, music (from the Greek is the art of muses) is interpreted as: "art that reflects reality in artistic and sound images"1; art in which feelings, mood, ideas are expressed in

${ }^{1}$ Гіптерс 3.В. Культурологія: Словник-довідник. Київ : УБС. НБУ, 2008. 407 с. 
combination of sounds and tones; harmonic sound of something ${ }^{2}$; sound that has a specific form of organization, intonation, rhythm, through which the influence on the person's feelings is done ${ }^{3}$. The basis of typing in music is the musical (artistic and sound) image, which often includes an element of sound imaging (for example, means of imitation of a certain sound, motor associations). The generalizing power of musical images increases significantly when compared, alternated, and contrast ${ }^{4}$.

In the philosophical aspect, music is a spiritual category, and the spiritual nature of music has deep metaphysical roots. In the light of the metaphysical category of "the spirit of music", introduced by F. Nietzsche, live music, which sounds in everyday activities, is only a phenomenon of this spirit. The very spirit of music is some kind of "metamusic" that sings from the metaphysical depths of the universe and makes the "strings" of different realities to be heard, starting from the living space and to the human spirit and the musical instruments created by man ${ }^{5}$.

People's artistic feelings can be caused by connecting words, sounds and images. According to D. Shostakovych, music "can show millions of people what is done in the soul of one person and let one person discover what the soul of the whole mankind is filled with" .

In the theory of art pedagogy, musical activity occupies a significant place and is one of the main tasks of artistic education. Scientists from various fields of science engaged in studying the essence and content of individual components of musical activity, such as musical education motivation, the structure of musicality, musical-creative potential, musical competence, etc.

Preschool age is an important stage in personal growth of an individual, which creates the basis for dynamic changes in the further ontogeny of a person. It is this period that scientists compare with laying the basement in constructing a building, and the beauty and grandeur of the future construction will depend on the quality and reliability of basement. Domestic and foreign scholars note that preschool age has an exceptional sensitivity to musical activity, and is characterized by extreme emotion and curiosity, a naive-gaming character of cognition,

${ }^{2}$ Гончаренко С.У. Український педагогічний словник. Київ, 1997. 376 с.

${ }^{3}$ Петрушенко О.П. Словник з естетики. Львів, 2009. 353 с.

4 Там само.

${ }^{5}$ Ницше Ф. Рождение трагедии из духа музыки. Санкт-Петербург : Азбукаклассика, 2005. 208 с.

6 Шостакович Д.Д. Письма к другу: Дмитрий Шостакович - Исааку Гликману. Москва, Санкт-Петербург, 1993. 299 с. 
syncretism of artistic perception (L. Vygotsky, G. Ovsiankina, O. Rostovsky, etc.) as well as laying the foundation for future destinies, creating the basis for writing the main plot of the life scenario (J. Stewart, V. Jones, etc. $)^{7}$.

According to the logic of the child development, the formation of musical activities is in a certain sequence: the first stage is the musical and substantive activities (interest in objects that give sounds, accumulation of experience in manipulating them); the second is music and game activity (music becomes a source of emotional experience enrichment, social attitude in game and communication); the third one is the musical and artistic activity (the child begins to be interested in the process and result of the activity, emotional experience allows him or her to improvise musical works creatively). The experience of participating in musical activities enables senior preschool children to choose the most successful ways of their realization: the listener (the ability to evaluate music and express the results of their own perception); performer of musical works (dancer, singer, etc.); artist (improviser, author of a musical game, etc.). In the senior preschool age, the depth of the emotional experience is expressed in the ability to improvise not so much a figurative musical series, but so many nuances of mood, characters that are expressed in music ${ }^{8}$.

We fully agree with the statement of $\mathrm{N}$. Vetlugina that the link that unites the child and art is activity. Musical activity as a special kind of activity helps the growing person to understand him/herself, to know the environment, to comprehend the complex laws of human existence. Based on the positions of experts, it is possible to summarize that due to emotional content music objectifies, reinforces the desire of preschoolers to express themselves.

The improvisation in child creativity was discussed by P. Blonsky, N. Bryusov, N. Krupska, A. Lunacharsky and others. The idea that early childhood creativity is improvised is expressed by B. Yusov. In general, creativity is a mysterious process. In a truly high and broad sense, the concept of creativity is not accessible to many. However, in the life of our society, we face daily mass expressions of creativity in various

${ }^{7}$ Малашевська А.І. Теорія і практика навчання музики дітей дошкільного та молодшого шкільного віку з використанням музикотерапії : автореф. дис. ... докт. пед. наук : 13.00.02. Київ, 2017. 36 с.

${ }^{8}$ Онищук І.А. Розвиток творчого самовираження дошкільників у музичній діяльності : автореф. дис. ... канд. пед. наук : 13.00.08. Київ, 2012. 20 с. 
spheres. Science and musical art, all the achievements of human civilization, the very forms of human life are based on it.

Improvisation is considered to be an integral part of the creative process (arises during artistic and creative activity), as well as its result and means of improvement. Most researchers admit that the main thing in improvisation is the suddenness of creative impulse. In this regard, it is considered, as a special kind of artistic creativity, according to which its result is achieved directly during the performance, without preliminary preparation. The creative process in improvisation is characterized not only by spontaneity, but also by the fact that the product of creativity by way of implementation becomes inseparable from the creative act.

Let us refer to the terminological sources in which the phenomenon (from French improvisation, Italian improvvisazione, from Latin improvisus means unexpected, sudden) is interpreted as: a special kind of artistic creativity inherent in various types of arts (poetry, drama, music, choreography etc); creative act of artistic work formation without preliminary preparation during performance; the type of musical creativity, in which the product is created spontaneously, during performance; a kind of creativity, which is carried out quickly, directly, by fixing the free flow of associations ${ }^{9}$; creative method of performing the composition without preliminary training in front of the audience. Improvisation is also understood as a complex psychological process that stimulates the creation of a product and promotes the formation of an interest in creativity ${ }^{10}$.

Analysis of the phenomenon of "improvisation" interpretation makes it possible to conclude that there is no single definition of it. This is the type of artistic and musical creativity, the form of activity (creative, musical and practical, musical composition), creative act, the method of creativity, the creation of music without pre-training. The generalization of various approaches to the interpretation of this artistic phenomenon makes it possible to clarify this concept. Improvisation is a kind of artistic and creative activity, in the process of which a creative product is formed.

9 Літературознавча енциклопедія : у 2 т. / авт.-уклад. Ю.І. Ковалів. Київ : ВЦ «Академія», 2007. Т.1. 608c.

10 Васильєва М.П. Формування комунікативних умінь як компонента педагогічної культури майбутнього вчителя : автореф. дис. ... канд. пед. наук : 13.00.01. Харків, 1997. 23 с. 
Improvisation is not a new phenomenon in pedagogy. This is the kind of creativity "primary and ancient, and it arose then, when the main form of knowledge of a man of the world and of itself was the sensory perception of individual facts, and its corresponding form of reaction to specific images that arose in consciousness was direct instant feedback"11. For the first time, the term "improvisation" appeared at the end of the fifteenth century in Italy, in particular, in the palaces of the Dukes Turbino, Ferrari, Mantua, Milan and Naples. The improviserspoets who recited or sang to accompany a musical instrument on any proposed theme, composed poems without preparation, without written notes. Improvisation reached its high peak in the sixteenth and eighteenth centuries in the Italian comedy of the masks of "del arte" that is a special form of dramatic performances, in which the dialogues and replicas of actors were not strictly fixed and had a "living" natural, improvised character $^{12}$.

Whatever industry improvisation manifests itself, it is always a departure from the template. Famous musician-teacher B. Runin considers improvisation as an effective method of teaching musical performances. He suggests using the principle of individualization and differentiation to formulate tasks for improvisation ${ }^{13}$.

As D. Kabalevsky emphasized, improvisation classes are aimed at the development of intonational and orderly hearing, the formation of creative imagination ${ }^{14}$. The ability to improvise is not only internal will and boundless fantasy. This complex work requires certain musical knowledge and skills. The peculiar melodic and harmonic language of the improviser is formed because of painstaking and long-lasting work and directly depends on the personality of the musician, the level of his musical development and the means of musical expressiveness available in his arsenal. The lessons of improvisation are not just music classes, but also lessons of life. C. Orff, I. Carley believed that there was no more

11 Харькин В.Н. Импровизация... Импровизация? Импровизация! Москва : ИЧП «Изд. Магистр», 1997. 288 с.

12 Энциклопедический словарь / изд. Ф.А. Брокгауз, И.А. Ефрон. СанктПетербург: Типо-Литография И.А. Ефрона, 1994. Т. 13. С. 23-24.

13 Рунин Б.М. О психологии импровизации: Психология процесса художественного творчества. Ленинград, 1980. 176 с.

14 Кабалевский Д.Б. Педагогические размышления. Москва : Педагогика, 1986. $188 \mathrm{c}$. 
effective and reliable way to achieve this goal, as to teach improvisation $^{15}$.

Today, the art of improvisation is almost completely forgotten. Musicians who are able to make in front of the public are rarely seen. This happened primarily because in the music, as in all areas of our life, "narrow specialization" prevails i.e. the composers are now not concurrent concert performers, and professional instrumentalistsconcertans, as a rule, do not possess outstanding composer's skills. Old traditions of improvisation have survived only in some organists. In our timemany musicians feel the need to revive the traditions of musical improvisation in the context of academic music and musical education. Usually a composer, creating a work, premonitatively thinks about it, makes sketches, and then he writes a piece of music on the sheet, carefully processing each detail. However, it happens that the musician sits down for the piano, takes some chaotic chords, and then begins to play, as if pondering. Passages are heard; tunes appear and disappear, again changing spills of passages. Ask ... this musician what he was playing, and he will answer that it is nothing, just improvised. If, in essence, improvisation involves the performance of certain musical works, then, of course, this term can be used also in the context of musical activity, since in the senior preschool age, when there is a certain experience of musical feelings; children are capable of self-improvising of simple musical compositions.

Naturally, children's improvisation is a simple, somewhat naive music, which gives the opportunity to acquire a diverse experience: movement and speech, the first principles of music; listener, composer, performer and actor; communication, creativity and fantasy, selfexpression and spontaneity; the experience of music as joy and pleasure. However, under the skilful leadership of the teacher during the performance of various types of improvisations such as vocal, rhythmic and instrumental, the existing creative potential of children is revealed and developed.

The use of vocal improvisation at musical classes is the most widespread, since self-expression through voice; singing is embodied in the very nature of a man. the following tasks can be among the vocal creative ones such as question-answer, musical dialogue, a musical conversation between the teacher and children, the child and the child

15 Галузинський В.М., Євтух М.Б. Основи педагогіки та психології вищої школи в Україні : навчальний посібник. Київ, 1995. 168 с. 
(in pairs, triples), the task for the continuation or completion of the musical phrase of the poem, songs, etc. A musical game-dialogue, where the teacher will sing the beginning of some famous melodies (for fairy tales, for example), can be a vivid example, and the child needs to guess it and continue it (or to invent a melody, but to display it intonatively expediently and rhythmically). In such music and game-dialogues, it is important for the teacher to use a variety of songs, change the order of the melody, the genre and dynamics carefully. In music games, children have to take over the roles of listeners or performers in turn. To make the game more engaging, "critics" - listeners can be offered to evaluate the performance of those who improvise. For example, you can show cards that depict faces with different emotions (like - dislike). Therefore, children will gradually develop musical thinking, artistic taste, initiative, autonomy and responsibility. Children of preschool age are happy to respond to the teacher's suggestions to create vocal improvisation on simple rhythmic drawings, based on the following words repeating: child names, situational phrases, and onomatopoeia. Because of this activity, children develop the need for musical expression of their own emotions, an interest in the way of expressing emotions through music by other children.

In the performance process, the most distinct are personal creativity, aesthetic feelings, inspiration, and the "spirit of the winner" appear, the feeling of satisfaction with the work being performed. Therefore, for preschoolers who study the world of music, improvisational activity is necessary, and even desirable, because it is always connected with the favorite children playing activity. Performing any musical work always means playing it, acting on the principle of figurative and game entry into music. Therefore, the perfomance of even a short song demands from children new reincarnations, new penetration into the emotional and sensual world of the work every time. To realise this children can only due to visual associations ("movie tape of representations" by Konstantin Stanislavskyi), making the ability to see with "the inner sight" what they sing. Instead, the teacher has to:

- complete the "film", offering imagery pictures to children;

- focus children on performance, giving them the opportunity successfully realize creative tasks.

Note that all children, regardless of their level of musical giftedness of musical-improvisational activities, need to be involved. After all, the enthusiastic process of musical creativity the child will strive to achieve decent creative results, even for the temporary (due to lack of 
experience) intonational-auditory or verbal-logical limitation or imperfect motility.

Musical and rhythmic movements is one of the most powerful and necessary means of forming the personality of the child, because the movement is:

- The cornerstone of the child's physical health;

- The stimulator of spiritual and physical energy;

- The stimulator of creative forces.

Musical and rhythmic exercises help to prepare a senior preschooler for spontaneous motor expression, teach to depict sounds and mood through elementary movement (strikes, clicks, splashing, stepping), while they produce reaction speed, ability to wait, find the moment of entry. In the musical and rhythmic exercises, the child simultaneously performs and creates, as it invences movements, based on the nature, tempo, rhythm, timbre of the music offered to. The child begins to realize the music through movement.

At the elementary stages of musical education, it is difficult to find a more appropriate way of developing musical and rhythmic senses than musical and rhythmic games that are built on the embodiment of the music rhythm in simple and accessible children's movements. According to the Ukrainian composer, collector and researcher of the folklore Vasyl Verkhovytsya, rhythmically performed games unite children, because "such a property of the rhythm" turns the game into a serious group work, and the participants of the game are into a team united with common opinion. In turn, Carl Orff, the founder of one of the most effective systems of integrated musical activity, emphasized that without the bodily sense of the rhythm it is not possible to develop a sense of musical rhythm.

Note that improvisational and performing musical games have a comprehensive positive impact on children as they develop both body and mind, effectively stimulate creative imagination, thinking, inspire children to transform their experience creatively and innovate.

Instrumental improvisations are associated with the use of the simplest musical instruments on musical lessons, including noise ones and drums. If there are drums in the music room, then they can be used for rhythmic accompaniment of songs. Noise musical instruments are relevant when accompanying musical tales to create musical backgrounds (the noise of the forest, the rustle of leaves, the rustling of a stream, etc.). The use of self-made accessories is widely popular in working with children at musical lessons and they mimic certain 
instruments (chestnuts, pencils, etc.). One of the creative tasks for implementing group instrumental improvisation can be a musical tale, which will be accompanied by the use of a number of musical instruments. As a basis, you can take any well-known fairy tale, if there is an opportunity to reproduce a wide range of artistic images in it. An example of such a fairy tale may be the "Bear in the Forest", created by an educator along with preschoolers. Having distributed musical instruments to children, it is necessary to focus their attention on the development of fantastic events and on the purpose for which they should use their instruments: the drums (the bear goes on the street, running in the woods), the xylophone, the triangle, the bells (the squirrel leaping), the voice (the bears were flaming from the bites of the bees, the crow raged), bells (mockingbird), crows (fly bees, sting bees), pencils (beehive with bees), and others. It is very good when the teacher pays time for instrumental improvisation and teaches preschoolers to pick up subvoices, invent melodies with different melodic lines, rhythms, etc. Possession of such skills will help preschoolers in creating musical images, showing the character of a particular personage (wolf, mouse, bunny), even in certain musical genres (dance, waltz, mazurka).

Musical instruments and toys, such as bells, triangles, buboons, tambrushes, tambourines, rattles, bow instruments, xylophones, organs, castanets, tubers, cymbals, as well as homemade instruments, promote the development of musical and tembral hearing, the emotional and sensory sphere of a child. While playing music, children are creatively aware of the elements of musical language, its form, intonation, phrasing, nuances, strokes, simultaneously managing solo and group improvisation, being able to find new ways of sound production, interesting performances of "paint", etc.

So, as it turned out, the use of different types of musical improvisation at musical classes will contribute to a deeper knowledge of musical art and at the same time to the disclosure of a creative personality i.e. the assimilation of the intonational-figurative music system, the comprehension of its genre-stylistic nature, the formation of a deep emotional response to music, the production of artistic flexibility, development of associative thinking, creative imagination. The performance of a number of such tasks by senior preschool children depends on their skills and skills of the teacher and the choice of the methods of training musical improvisation. 


\section{Experimental methods of senior preschool age child creative-improvisational personality formation in musical activity}

Our research and experimental work was carried out within the framework of the research theme of the department of preschool education "Theoretical and methodical principles of the creative personality formation of preschool children in various activities" of Mykolaiv V.O. Sukhomlynskyi National University. We began it with the study of the state of the investigated phenomenon in modern practice of musical education. Children of senior groups (40 persons) were involved in the qualifying experiment, and were divided into 2 subgroups, they are the control group (CG) - 20 people, and the experimental one (EG), which is also 20 people, besides educators and music teachers of pre-school establishments were involved.

The constitutive experiment of the study included three areas:

- The study of modern approaches to the organization of children's improvisation in the conditions of the existing system of preschool musical education;

- The identification of levels of creatively improvised personality formation of the senior preschool age child in musical activity;

- The finding out the dependence of the level of musical development of children on their available experience of musical improvisation.

During this period, the number of children in groups changed a little (some children left the institution of preschool education). Despite this, other children entered the group, so the number of children remained unchanged. Experimental research was carried out in groups of general development. Children were not specifically selected and the social status of all families was approximately the same.

The program of the constitutive experiment provided for the use of such methods as collective and individual polls of preschool children, interviews, diagnostic group and individual tasks for children of the senior preschool age, pedagogical observation of independent and organized musical activities, and questionnaires of respondents: educators, music teachers.

The analysis of the results of the questionnaire revealed both the advantages and disadvantages of the existing practice of preschool musical education. Among the advantages are teachers' initiative and great enthusiasm in the development of preschool music education, in spite of all the difficulties they meet. A big disadvantage is that most teachers prefer the methods of musical education, oriented only on reproduction of 
the sample without its further transformation. Moreover, this, in turn, contradicts the improvisational and creative nature of children's musical performances. In addition, teachers, due to objective factors, involve children, mainly for singing and motor performance, without taking into account the developing potential of instrumental music.

The second area of the constitutive experiment required the identification of criteria and indicators for the formation of the creative and improvised personality of the senior preschool age child in musical activity in accordance with its component structure. Cognitive and gaming criterion with indicators such as independent performance of the learned song from the beginning to the end; performing several different movements in motor improvisation on a given musical accompaniment; knowing several ways of playing on each of the proposed musical instruments.

Emotion and expressive criterion with indicators such as combining the singing with motor and rhythmic improvisations; the production of original movements in improvisation for a given musical accompaniment; completing instrumental music with singer and motor improvisations.

Creative and activity criterion with indicators such as melodic hearing in accurate reproduction of song melodies; the sensation of rhythm in motor improvisations on the given musical accompaniment; dynamic hearing in reproduction of given dynamic changes in the musical and improvisation accompaniment.

The outlined criteria and indicators provided the basis for the identification of the levels of the creative and improvised personality formation of the senior preschool age child in musical activity.

The high level is reflected in the independent performance of the learned songs without any help by the adult, application of several different movements in accordance with the nature of musical accompaniment in musical and motor improvisations, the reproduction of completed rhythmic patterns and melodic singing, using several methods of play on each of the proposed instruments; in improvising their own singing on the themes of familiar songs, completing singing performances by motor and rhythmic improvisations, inventing original movements and compositionally completed dance improvisations, adding the instrumental music by singing and motor improvisations; acomponying their own performances with adequate expressive facial expressions, pantomime and gestures, emotional expressions about their own performing and performing music. The high level also involves free orientation in the names of the studied songs and musical instruments, 
the verbal definition of the parts of the song (coupon - chorus) and stylistic accessories of musical accompaniment, using examples of march, polka, waltz, as well as the concept of the orchestra as a result of their own participation in group improvisation.

The average level is manifested in the performance of mastered songs with the help of an adult, monotony and repetition of improvised movements for given musical accompaniment, reproduction of rhythmic movements and melodic singing, using only one method of play on each of the proposed instruments. At the same time, performing creativity and emotional expression can be seen not in every, but in some kind of musical-improvisational activity. The confusion may be in verbal definition of the main moments of their own improvisation.

The low level is characterized by incomplete performance of learned songs (or chorus or couplet), partial reflection in their own movements of the nature of musical accompaniment, weak possession of playing techniques on several musical instruments without the possibility of further reproduction of a completed rhythmic pattern or episode, partial revealing of performing arts and emotional expressiveness in isolated actions, and a verbal definition of an insignificant amount of musical knowledge due to their own improvisation.

In the process of organizing the experimental work, we were guided by the relevant principles of creatively improvised personality of the senior preschool age child in musical activity.

Under the principle of organizing experimental teaching, we understand the starting points that determine the success and effective creative development of the personality of senior preschool children in all aspects of experimental learning. They are content, forms of organization, methods, techniques, motives and value orientations. The leading principles of organizing experimental training and education were:

- Principle of humane interaction of the teacher and children

The implementation of this principle ensures a person-oriented approach and value attitude to the child, the cultivation of the unique personality, the need to recognize its subjective experience as an individual basis for personal development.

This principle ensures that every child has the right to recognize his/her in a society as a person, respectful and benevolent attitude. This principle is expressed in the acquisition of a child of the image, creative beginning, and independence of individuality. This allows lying the mechanism of self-realization, self-development, self-education, 
necessary for the formation of a distinctive person, dialogical interaction with people, nature, and culture.

- Principle of co-creation

Co-creation is the objective process of joint search of truth. This principle involves the creative interaction of pupils and educators, pupils with each other in the process of musical improvisation activities. Joint activity in the conditions of musical education, which means creation of a certain microclimate in the creative group. The search character produces an interaction that does not have an unambiguous decision in the problem study. The combined creative activity leads to a change in the relationship between the teacher and the pupils, promotes the learning of the dialogic style of communication by the pupils. The most important thing in this style is the humanistic orientation towards cooperation in activity, the strategy of equality in communication.

Thus, based on the principle of co-creation, an educational process can be built, which will contribute to the formation of a creative and developed personality. Realizing this principle, it is important to remember that the success of its implementation is determined by the place, assigned by children to the author's creativity.

- The principle of syncretism

Research opinion rightly considers syncretism as a combination of equal components of artistic creativity subordinated to a single ideological and aesthetic concept, such as word, movement, and music. In the conditions of musical education, it is precisely syncretic activity that is the most adequate means of taking into account age-specific characteristics, thanks to syncretism, the scope of artistic and aesthetic expression of the child's personality is expanding. In addition, these activities, by virtue of their syncretism, contribute to the optimal development of creative abilities such as imaginative thinking, productive imagination, empathy, an advanced emotional evaluation of an object in a problematic situation, etc. This means that it is precisely syncretic activity in the studied conditions that is the source of the implementation of one of the key settings of personality-oriented education, versatile creative development of personality ${ }^{16}$.

- Principle of learning in action

Modern understanding of the development of creativity anticipates involving children in the process of communicating with music on the

16 Гіптерс 3.В. Культурологія: Словник-довідник. Київ : УБС. НБУ, 2008. $407 \mathrm{c}$. 
basis of activity. The research idea fairly proves that the movement is primary. Movement is the main factor of adaptation; it manifests itself at an early age, when the assimilation of reality takes place. This principle allows a child, along with a teacher, to participate in the process of active creative action. Connection of music with movements and language is one of the provisions of children's musical creativity. The implementation of this principle appears from the following provision that music should not be on its own, everyone must take part in the process of creating music. Music relies on the linguistic and mobile-plastic experience of life. This connection is due to the biological nature of man.

Thus, based on this principle there is the development of auditory and motor, visual and spatial coordination, musical hearing, general movements and the creative and emotional sphere of the child.

- The principle of improvisation

This principle ensures the formation of improvisational thinking, the ability to fantasize, combine familiar material in language, mobile exercises and do it spontaneously, which creates the preconditions for linguistic and plastic improvisations. Improvisation is always associated with risk, which is why the implementation of this principle orientates the educator into activating the independence of children, the flexibility of thinking, the search for their own, spontaneous decisions, various ideas to solve the problem. Variance and improvisation presuppose the relation of children to sound, word, gesture, movement as a game material, which creates the foundation for creativity. It is important to note that this principle differs in terms of simplicity and accessibility in the process of musical activity.

- The principle of positive emotion is because in the preschool age, the behavior and actions of the child are driven by its internal needs, closely linked to the center of positive emotions. In order to understand this, it is enough to remember oneself in a childhood, or to observe preschoolers who sing their favorite songs, beat drums, move lively dances, and so on. It is unlikely that the inner motive of their actions is the desire to know something, as if the reaction of adults. Most likely, in a moment of such musical activity, the child just rejoices. It is in the conditions of the joy that the teacher is able to educate children sincerely and solid love to music for life. Therefore, the child's own actions and the actions of the adults she mimics, musical images and games about them should be filled with pleasant emotional experiences.

Research results and their discussion. Experimental work was preceded by the definition of pedagogical conditions for the effective 
formation of creatively improvised personality of the senior preschool age child in musical activity.

A condition is a necessary condition that enables the exercise, creation, or promotion of something ${ }^{17}$.

Under the pedagogical conditions, we understand the external circumstances concerning the organization of the educational process in preschool education, which are the cause and the stimulus of qualitative positive changes in personal development, in particular the formation of a musical and creative person, in relation to the personality of the preschool child.

- Active inclusion of children in musical improvisation activities in the syncretic unity of its types;

- Purposeful activation of emotional and creative manifestations of children in the process of various styles and genres of music development;

- Benevolent support for the independence and creativity of children in musical improvisation activities.

The implementation of the experimental methodology has begun a preparatory-imitative stage, the purpose of which was the formation of children's experience of musical improvisation. At this stage, the traditional musical repertoire was used such as program songs and plays, as well as the best examples of children's musical folklore.

The preschoolers acquired the musical stuff in the process of emotionally expressive reproduction of musical and practical actions by the model presented by the teacher, using the methods of musical-stylistic transformations of the children's repertoire, the integration of various types of musical-performing activities and the manipulation of elements of musical expression. The basis of the method of musical-stylistic transformations was the idea of $\mathrm{T}$. Tyutyunnikova about stylistic transformations as "transferring" famous music to other clothes, which the children "actively listen to", while improvizing the rhythmic accompaniment to it, which corresponds to the very essence of creative music ${ }^{18}$. The introduction of this method in the practice of preschool musical education and upbrining best suits the peculiarities of modern musical culture,

17 Энциклопедический словарь / изд. Ф.А. Брокгауз, И.А. Ефрон. СанктПетербург : Типо-Литография И.А. Ефрона, 1994. Т. 13. С. 23-24.

8 Тютюнникова Т.Э. Видеть музыку и танцевать стихи... Творческое музицирование, импровизация и законы бытия. Москва : Едиториал УРСС, 2003. 264 c. 
characterized by constant updating, interpenetration and a combination of different styles. For example: under the musical accompaniment in the march style, the children were improvised on drums, under the musical accompaniment in the polka style they were jumping jumps, waltz style musical accompaniment children were singing lyrical songs and performing smooth movements in pairs and with attributes.

Implementation of the method of integration of various types of musical improvisation activities included the assimilation by children of examples of interaction between types of musical activity (singing, musical-rhythmic movements, playing children's musical instruments) by means of musical-gaming complexes.

For example, a game task can be highlighted in a plot song, but solved in dance or instrumental improvisation. At the same time, the song and improvisation are performed by the children themselves. It enhances the developmental value of many musical works, even the simplest, because through the rules of the game, the plot and the roles, preschoolers are more emotionally responsive to changes in musical accompaniment, they often show a creative initiative. Such pedagogical condition as active inclusion of children in musical improvisation activity in the syncretic unity of its species is realized. This work was carried out in stages.

Illustrating with an example.

Task 1. "Who came to visit?" Purpose: to find out the ability of children to convey the nature of a musical composition according to the lyrics in singing, to improvise on musical instruments.

Material: toys that match the musical image (toy-cock, toy-cat, toycrane, toy-bee).

Procedure of realization. The teacher invites children to see who came to visit them. When the children greet guests, the teacher alternates performances on piano playing: Ukrainian folk singing "My North", V. Verkhovytsya's music "Kitten, kitten, meow". The child must sing rhythmically with musical accompaniment, and then without it, respectively transmitting the character of the melody and supplementing the improvised play on the children's musical instrument (at the choice of the child). Then the music director suggests singing familiar to children song: music by A. Filippenko, words by T. Volhina "Oh, crane"; the music by K. Myaskov, the words of G. Boyka "The Bee Comes", rhythmically at a pace, with dynamic shades. 
Task 2. "Song Clock". Purpose: to find out the ability of children to improvise, to transfer the character of familiar songs melodies by corresponding movements.

Equipment: clock $(25-30 \mathrm{~cm}$ in diameter), on the edges of which pictures with of fairy-tale characters images are fixed (Joker, squirrel, fox, frog), noise instruments.

Procedure of realization. The teacher offers the child to listen to fragments of songs melodies: music and words by N. Veresokina "Petrushka", music by T. Grosu, words of G. Boyko "Squirrel", music and words by N. Rubalskaya "Song of Fox", music and lyrics by Y. Litovko "Merry frogs". After repeatedly listening to the musical works, the child should recount the character after the rhythm, tilt the rhythm on the noise instruments and point the corresponding picture on the song clock. Then the teacher offers the child to imagine her/himself (Joker, squirrel, fox, frog), to think and improvise the dance, to try to convey the nature of music with appropriate movements and gestures.

The task is repeated 2-3 times (with a sequence change).

Task 3. "Musical Riddles". Purpose: to find out the ability of children to distinguish between musical instrument tones and to pick a simple rhythmic drawing of melodies on children's musical instruments.

Equipment: musical instruments (bells, cymbals, triangle), a screen.

Procedure of realization. The children sit in a semicircle in front of the screen, behind which the musical instruments are on the table. The teacher plays a fragment of the Ukrainian folk melody "Grechanyky" on one of the instruments. The child must recognize the musical instrument according to the timbre of sound, and depict fragment of a rhythmic drawing on it, to convey the characteristic features of a musical composition. The task is repeated twice.

The second stage is reproductive-activity, that envisaged the immersion of senior preschool children in active musical improvisation activities. Traditional musical repertoire was completed by works of contemporary Ukrainian and foreign composers. Each new musical composition was mastered by children in situations of variation and improvisation. In the conditions of revitalization of preschool children performing work, it was pedagogically expedient to use the method of directed involvement of children in improvisation. This method became a logical continuation of the method of manipulating the elements of musical expression and consisted of a supervised teacher improvisation of preschoolers, in which they were able to originally use and thereby expand the experience gained in musical improvisation. Creative tasks 
are aimed at the development of fantasy; ability to convey your feelings, mood; ability to accumulate observation, their embodiment in improvisations, in role games, in musical dialogues; the skills of inventing the simplest melodies, singing, intonations in a certain rhythm, minor or major order; ability to embody in verbal, pictorial, plastic improvisations their own impressions about the artistic phenomenon, musical work.

For example, vocal improvisation may be aimed at inventing a melody: on a certain emotional and figurative situation; on the genre (march, polka, waltz); to a certain mood; on the given order (major or minor); on the given rhythm (waltz, dashed rhythm); to a certain form (song, dance march).

In instrumental improvisations, the teacher offers children to create their own orchestra based on a particular musical composition. Familiar with this work, children determine its character and genre affiliation (depending on the style of the teacher). Children also have the opportunity to choose from the proposed musical instruments those ones whose sound corresponds to the nature of the music they have heard. The teacher surely reminds that playing these instruments is possible only when the music sounds, setting the children for improvisation at a given pace and metro rhythm, but at the same time with music.

The children gradually became accustomed to the harmonious reproduction of the metric pulsation of musical accompaniment, and some of them quickly mastered the foundations of harmonious improvisation, inventing their own completed rhythmic patterns within a given metric pulsation.

At the reproductive-activity stage, such a pedagogical condition as the purposeful activation of the emotional and creative manifestations of children in the process of mastering various styles and genres of music was realized.

Illustratting with examples of lesson notes and game tasks.

Task 1. "Rolling sack". Purpose: to find out the ability of children to improvise according to contrasting parts in music.

Equipment: a small bright sack.

Procedure of realization. A group of children stays in a circle and handles a sack with the words:

The sack was thrown

From the high hump.

To whom the sack will fall,

That dance will be crowned. 
The child who has the sack is in the middle of the circle and performs his improvised dance for musical accompaniment: Ukrainian folk melody "Kozachok", Ukrainian folk melody "Oh, burst a hoop", music by K. Stetsenko "Dance of autumn leaves", music and words N. Tkachenko "Droplets".

Task 2. "Quietly and quietly". Purpose: to fix the ability to distinguish between the dynamic shades of music: silently (p), loud (f), not very loud (mf).

Equipment: A card divided into three squares. Three small cardssquares of the same color, but different in saturation, (one orange, the other one is pink, the third one is burgundy), which conditionally correspond to a certain dynamic tint. The orange card corresponds to the quiet sound of the music; pink means a loud sound and a card of burgundy color is for the loud sound of music.

Procedure of realization. Children are given cards and the meaning of them is explained. Then they listen to a musical work, where dynamic shades are changed in sequence: from the non-loud (mezzo forte) sound of the first part to the quiet (piano) of the second and loud (forte) the third part. The play is repeated twice. At first, children are listening to music. When re-played, they put on the card the squares, corresponding to the color of the dynamic shades of music. Then the teacher suggests to improvise on a musical instrument and either sing a song or improvise the dance according to dynamic shades.

To enhance the interest and emotional activity of children, a musicaldidactic mobile game, a stage version of a small fairy tale, where the children, depicting different heroes, had to improvise sing, dance, play in accordance with the dynamic nuances: "loudly", "quietly", "a little quieter", "a little louder" and depict it. Each time the charectors were played by children with different levels of dynamic hearing formation, and day by day one could observe something new with elements of creativity of children.

Musical lesson: "We have fun flowers". Purpose: listening - to determine the genre of musical work, the character and means of musical expression in the work of P. Tchaikovskyi "Waltz of Flowers" from the ballet "Nutcracker". Improvising to change movements in accordance with the dynamic nuances, complete the performance of movements simultaneously with music. With the help of gaming situations, promote deep immersion of children in creative musical improvisation activities, to cause a desire to do it. Singing - be able to recognize the introduction of a familiar song "Good in our garden", music by V. Gerchyk, the 
words of A. Prysheltsia; - to be able to sing in a natural voice, correctly reflecting the melody of the song, the nature of music (dynamics, pace). Playing musical instruments - identify the ability to improvise a familiar song on one of the suggested musical instruments (on choice).

Equipment: audio recording of a musical composition, whistles, headbands with flowers, chocolate sticks with floral scents, drawings with flowers, musical instruments (metalophone, triangular, bubo, maracas).

Lesson record (fragment)

Teacher: Kids, imagine that each of you is a little charming flower. Listen carefully to the melody to determine which mood it is transmitting. (Sounds in the recording of "The Waltz of Flowers" from Pyotr Tchaikovskyi's "Nutcracker" ballet. Having listened to the melody, the children determine the character of music: light, joyful, tender, sunny, beautiful, etc.).

Teacher: - What can you do with this music: sing, step or dance? Right, and what dance can it be: polka, waltz or folk dance?

Teacher: - Yes, this dance is called "Waltz of Flowers"; written by his famous composer Peter Ilyich Tchaikovskyi. In addition, what does the word "waltz" mean, who remembers? (Children's answers)

Teacher: - Let us circle around the sounds of this great music.

(Children wear headscarves featuring flowers and improvise, performing arbitrary movements, whirling around the hall).

Teacher: And now I am going to play the introduction of a song, the one who recognizes it, clap your hands (the song). That is right, this song is called "Good in our garden", and the first one recognized it was Dima. Who wants to sing? Good for you, almost everyone. Let us do it together.

Do you remember how to sing it? Yes, this song is fun, dancing, and we should sing it merrily, so that everyone wants to dance.

Under the music accompaniment of a teacher, children perform a song, supplemented by improvised movements.

Teacher: Now, Katya N. and Roma L. will play, each on their musical instrument, the melody of the song (in turn). Watch the kids so that you correctly transmitted the nature of the melody, tempo and dynamic shades, and all the others listen to them carefully and say whose part impressed you more and who was closer to the original.

Individually-group classes. "Help the Bear". Purpose: the creation and improvisation skills in musical-rhythmic movements formation (afternoon). 


\section{Material: Toy Bear.}

Record of the lesson

The teacher says that today the Bear came to visit them. It asks for help from children as on the island of "Musical education" everyone laughs at him because he cannot dance at all. The teacher proposes to fulfill the task of creative direction ("dance competition"). Children choose their partner and perform their improvised dance under the melody offered by the teacher. The rest of the children, together with the Bear, appreciate each pair and choose the best one.

Thematic project "In the store". "The store of musical toys". Purpose: to teach to distinguish the sounds of musical instruments in timbre and force of the sound, to strengthen the ability to improvise, to develop the senses of the rhythm, to create a positive-gaming mood.

Equipment: a bell, large and small drums, musical instruments and toy-tools, a screen, framed under the showcase of the store, pictures depicting musical instruments.

Game options:

I. Having equipped the center of artistic activity under the shop of toy-tools, children independently distribute the roles of buyers and the cashier.

Children choose the goods themselves without a seller' help in the shop. The cashier passes them on condition of describing the selected musical toy-instrument and showing the play on it (improvisation).

II. The screen is equipped as a toy store. It hangs pictures depicting musical instruments. The child approaches the screen, greets the seller, and shows the tool that he wants to buy, asks for its price. An adult vendor offers to listen to the sound of several tools, among which the buyer must recognize the desired tool, to improvise it on a given topic and only then, he will be able to buy it. If you do not recognize the timbre of the instrument, or you are not able to improvise, then it remains without a purchase.

At the end of experimental work with senior preschoolers, a concert "Creative talents" was held, the repertoire of which included various types of songs, in which the emotional states, feelings, friendship were praised. Children performed familiar songs, improvised, thought up the ending of songs, accompanying musical instruments, inventing creative tasks. The result was the acquisition of senior preschoolers the ability to improvise, create, fantasize, interact, rhythmically move and sing.

The purpose of the third - productive and creative stage was to intensify the musical activity of children through improvisation. For this 
purpose, audio recordings with the best samples of various music were selected. So that the children would surely hear them and learn to move along harmoniously, play music in the ensemble, improvise, if possible, would sing and invent their own music plays. Besides, the method of including multimedia in the children's musical performance was added. This method was implemented by children performing songs under the phonograms "minus-voice", as well as by receiving media recording of the results of musical improvisation activities. Due to vocal improvisation, under the "minus voice" phonogram, children were able to feel themselves real artists, and competent engagement with such improvised singing positively affected the expressiveness of children's performance of songs.

In the experiment, the senior preschoolers were offered specially selected sketches, plays, creative exercises and tasks that contributed to the formation of the need and ability to realize themselves in the process of various types of musical activity.

The systematic use of the method of introducing musical information into the memory of children during sleep hours (natural daytime sleep), greatly increased the effectiveness of musical developmental influence, through strong and conscious assimilation of music repertoire by preschoolers. Within the limits of this method, it was used the music, which children had to learn better for the further performance in classes and holidays (audio recordings of songs, orchestrations, musical accompaniment to plays and dances, etc.). Along with this, the best examples of relaxation instrumental music were used (works by A. Vivaldi, I. Bach, V. Mozart, E. Grieg, C. Debussy, P. Tchaikovskyi), lullabies, etc. D. Jackobson relaxation exercises and plays are used to remove physical and mental stress, create a positive emotional mood, mastering the simplest skills of correcting their own psychosomatic state. In addition, the conditions of usage of exercises of dance-rhythmic improvisation were created, namely, dance-playing gymnastics "Sa-PhiDanse", which gradually gains its place in musical activities. This is facilitated by the positive emotional background of classes, compulsory diversity musical accompaniment, an unusual improvised combination of movements.

Specificity of dance-gymnastics is a combination of basic exercises with elements of dance of different styles, a close connection of movements with music and rhythms, high dynamism and variety of movements, as well as enrichment of motor experience and enhancement of the culture of movements' realization. 
The game method gives the educational process an attractive form, facilitates the process of memorizing and assimilating exercises, improves the motor activity of children, increases the emotional background of classes, promotes the development of thinking, imagination and creative abilities of the child.

Dance-gymnastics "Sa-Phi-Danse", authors Zh. Firilova, O. Sayikina, purpose is to promote the comprehensive development of the personality of preschool child by means of dance-gymnastics. The content of the program is interrelated with programs for the physical and musical upbringing of preschoolers.

The main objectives of the program are to strengthen health; to develop psychomotor and creative abilities, thinking, imagination and cognitive activity; liberalize; to form skills of emotional expression of movements for music, looseness and creativity in movements. It realizes the main tasks of the educational components "The Child in the World of Culture" and "The Personality of the Child"19.

In the course of our experimental work systematic analysis of the records of observations and plans for musical education of children and some changes to work were made. At the final stage of the study, a control section was conducted in order to identify the effectiveness of the experimental methodology for the formation of the creatively improvised personality of the senior preschool children. The children were asked to complete the tasks for each of our criteria and indicators set out in the same way as at the qualifying stage.

Primarily, quantitative and qualitative changes in the children of the senior preschool age concerning their musical education were determined.

Quantitative and qualitative shifts were recorded during the comparative analysis of the levels of creatively improvised personality formation of the senior preschool age child (the final section). The data are given in the table.

${ }^{19}$ Базовий компонент дошкільної освіти в Україні. К.: 2012. 26 с. 
Table 1

Comparative data of levels of creatively improvised personality formation of senior preschool children at the final cut, \%

\begin{tabular}{|c|c|c|c|c|c|c|}
\hline \multirow{2}{*}{} & \multicolumn{6}{|c|}{ Levels } \\
\cline { 2 - 7 } & \multicolumn{2}{|c|}{ High } & \multicolumn{2}{c|}{ Medium } & \multicolumn{2}{c|}{ Low } \\
\cline { 2 - 7 } & $\begin{array}{c}\text { Before the } \\
\text { experiment }\end{array}$ & $\begin{array}{c}\text { After } \\
\text { the } \\
\text { experi } \\
\text { ment }\end{array}$ & $\begin{array}{c}\text { Before the } \\
\text { experiment }\end{array}$ & $\begin{array}{c}\text { After } \\
\text { the } \\
\text { experi } \\
\text { ment }\end{array}$ & $\begin{array}{c}\text { After } \\
\text { Before the } \\
\text { experiment } \\
\text { the } \\
\text { experi } \\
\text { ment }\end{array}$ \\
\hline G & 25,3 & 63,3 & 30,8 & 24,2 & 43,9 & 12,5 \\
G & 20,2 & 43,3 & 29,2 & 30,8 & 50,6 & 25,8 \\
\hline
\end{tabular}

According to the table, the experimental group, $63.3 \%$ of children reached the high level of creatively improvised personality formation of the senior preschool age children (before it was 25.3\%), on average $24.2 \%$ of children (it was $30.8 \%$ ) and low level is $12.5 \%$ of children (it was $43.9 \%$ ). Thus, the experimental group showed positive changes in all levels of creatively improvised personality formation of the senior preschool age children. The obtained experimental data confirmed the effectiveness of pedagogical conditions, developed an experimental technique for the implementation of musical improvisation activities in the formation of the creative personality of a senior preschool age child.

\section{CONCLUSIONS}

The study does not cover all aspects of the identified problem. The prospects for its further research are seen in determining the means for ensuring continuity in the creatively improvised personality formation of the senior preschool and elementary school age children; revealing the influence of improvisation on the musical education of preschool children on the success of their studies at the New Ukrainian School.

Naturally, children's improvisation is a simple, somewhat naive music, which gives the opportunity to acquire a diverse experience: movement and speech, the first principles of music; listener, composer, performer and actor; communication, creativity and fantasy, selfexpression and spontaneity; the experience of music as joy and pleasure. However, under the skilful leadership of the teacher during the performance of various types of improvisations such as vocal, rhythmic and instrumental, the existing creative potential of children is revealed and developed. 
So, as it turned out, the use of different types of musical improvisation at musical classes will contribute to a deeper knowledge of musical art and at the same time to the disclosure of a creative personality i.e. the assimilation of the intonational-figurative music system, the comprehension of its genre-stylistic nature, the formation of a deep emotional response to music, the production of artistic flexibility, development of associative thinking, creative imagination.

"The child is creating the world" - to these words can be added only a small wish for adults: give the child a safe developing space in which the need for creative self-expression will find its way out. It can become musical improvisation activity, if it is competent and professionally organized by a teacher.

In addition, musical improvisation is the informational space of the child from which he/she receives information and transforms it into knowledge and understanding of the great world of music, its beauty; culture and musical heritage, the creator; about ourselves and our possibilities to create a model of the world in musical images and acquire the experience of sensual and emotional, artistic and figurative, aesthetic attitude to the reality, that is, the child becomes a creative personality.

\section{SUMMARY}

The article substantiates the concept of forming the creative personality of older preschool children by means of musical improvisation. The essence and structure of the studied phenomenon "creative-improvisational personality of a preschool age child" is determined and scientifically substantiated. The factors of effective influence on the formation of the creative personality of older preschool children (the use of various types of music improvisation in music lessons, which will contribute to a solid knowledge of musical art and at the same time the disclosure of creative personality: assimilation of intonation-shaped music style, natural understanding of the emotional response to music, development of artistic flexibility and associative thinking, creative imagination) are determined.

The criterion (cognitive and gaming criterion, emotion and expressive criterion, creative and activity criterion) with their indicators are defined; the levels of formation of the creative-improvisational personality of a preschool-age child in musical activity (high, medium, low) are characterized. In the process of organizing the experimental work, we were guided by the relevant principles of creative and improvisational personality of a preschool child in music: (the principle of humane 
interaction between the teacher and children; the principle of co-creation; the principle of syncretism; the principle of improvisation; the principle of learning in action; the principle of positivity. The experimental work was preceded by the process of defining of the pedagogical conditions for the effective formation of the creative-improvisational personality of a pre-school-age child in musical activity (active inclusion of children in musical-improvisational activity in the syncretic unity of its types; purposeful activation of emotional and creative processes; friendly support for the independence and creativity of children in music and improvisation activities). The experimental method of forming the creative-improvisational personality of a preschool-aged child in musical activity was developed and tested.

\section{References}

1. Базовий компонент дошкільної освіти в Україні. Київ, 2012. $26 \mathrm{c.}$

2. Васильєва М.П. Формування комунікативних умінь як компонента педагогічної культури майбутнього вчителя : автореф. дис. ... канд. пед. наук : 13.00.01. Харків, 1997. 23 с.

3. Галузинський В.М., Євтух М.Б. Основи педагогіки та психології вищої школи в Україні : навчальний посібник. Київ, 1995. $168 \mathrm{c}$.

4. Гіптерс 3.В. Культурологія: Словник-довідник. Київ : УБС. НБУ, 2008. 407 с.

5. Гончаренко С.У. Український педагогічний словник. Київ, 1997. 376c.

6. Кабалевский Д.Б. Педагогические размышления. Москва : Педагогика, 1986. 188 с.

7. Літературознавча енциклопедія : у 2 т. / авт.-уклад. Ю.І. Ковалів. Київ : ВЦ «Академія», 2007. Т. 1. 608 с.

8. Малашевська А.І. Теорія і практика навчання музики дітей дошкільного та молодшого шкільного віку 3 використанням музикотерапії : автореф. дис... докт. пед. наук : 13.00.02. Київ, 2017. 36c.

9. Ницше Ф. Рождение трагедии из духа музыки. Санкт-Петербург : Азбука-классика, 2005. 208 с.

10. Онищук I.А. Розвиток творчого самовираження дошкільників у музичній діяльності : автореф. дис. ... канд. пед. наук : 13.00.08. Київ, 2012. 20 с.

11.Петрушенко О.П. Словник з естетики. Львів, 2009. 353 с. 
12.Рунин, Б.М. О психологии импровизации: Психология процесса художественного творчества. Ленинград, $1980.176 \mathrm{c}$.

13.Тютюнникова Т.Э. Видеть музыку и танцевать стихи... Творческое музицирование, импровизация и законы бытия. Москва : Едиториал УРСС, 2003. 264 с.

14.Харькин В.Н. Импровизация... Импровизация? Импровизация! Москва : ИЧП «Изд. Магистр», 1997. 288 с.

15.Шостакович Д.Д. Письма к другу: Дмитрий Шостакович Исааку Гликману. Москва - Санкт-Петербург, 1993. 299 с.

16.Энциклопедический словарь / изд. Ф.А. Брокгауз, И.А. Ефрон. Санкт-Петербург : Типо-Литография И.А. Ефрона, 1994. T. 13. C. 23-24.

\section{Information about the author: Lisovska T. A., $\mathrm{PhD}$, Associate Professor,} Associate Professor at the Preschool Education Department V. O. Sukhomlynskyi Mykolaiv National University 24, Nikolska str., Mykolaiv, 54017, Ukraine 